\title{
Erratum to: Simultaneous detection of multiple targets for ultrastructural immunocytochemistry
}

\author{
V. V. Philimonenko • A. A. Philimonenko - I. Šloufová • \\ M. Hrubý • F. Novotný $\cdot$ Z. Halbhuber • M. Krivjanská • \\ J. Nebesářová $\cdot$ M. Šlouf $\cdot$ P. Hozák
}

Published online: 20 February 2014

(C) Springer-Verlag Berlin Heidelberg 2014

\section{Erratum to: Histochem Cell Biol \\ DOI 10.1007/s00418-013-1178-6}

In the Acknowledgements section of the published paper, part of the grant source by the Grant Agency of the Czech Republic number was omitted. The complete grant source of the Grant Agency of the Czech Republic should read as P205/10/0348, P305/11/2232 and P205/13/20110S.

The online version of the original article can be found under doi:10.1007/s00418-013-1178-6.

V. V. Philimonenko · A. A. Philimonenko · P. Hozák $(\bowtie)$ Institute of Molecular Genetics, Academy of Sciences of the Czech Republic, Vídeňská 1083,

14200 Prague 4, Czech Republic

e-mail: hozak@img.cas.cz

I. Šloufová

Department of Physical and Macromolecular Chemistry, Faculty of Science, Charles University in Prague, Hlavova 2030, 12840 Prague 2, Czech Republic

M. Hrubý · M. Šlouf

Institute of Macromolecular Chemistry, Academy of Sciences of the Czech Republic, Heyrovského nám. 2, 16206 Prague 6,

Czech Republic
F. Novotný

Faculty of Nuclear Sciences and Physical Engineering, Czech

Technical University in Prague, Břehová 7, 11519 Prague 1,

Czech Republic

Z. Halbhuber · M. Krivjanská

Central European Biosystems, s.r.o., Nad Safinou II 365,

25242 Vestec, Czech Republic

J. Nebesářová

Institute of Parasitology, Biology Centre, Academy of Sciences of the Czech Republic, Branišovská 31, 37005 Ceske Budejovice, Czech Republic 